\title{
EEN HUIS VOL INDONESISCHE KUNST
}

\section{De collectie van Frits Liefkes}

Van 9 mei tot 21 juli 2013 is in Rijksmuseum Volkenkunde in Leiden een speciale tentoonstelling te zien, gewijd aan de 200 mooiste stukken uit de collectie van wijlen Frits Liefkes, een waardevolle verzameling die het museum drie jaar geleden als legaat heeft ontvangen. ${ }^{1}$

Een jaar of zes geleden maakte ik kennis met Frits Liefkes (afb. 2) toen ik bij hem thuis, in de Frederikstraat in Den Haag, zijn bijzondere collectie Indonesische kunst en materiële cultuur kwam bekijken. Ik was onder de indruk van de hoge kwaliteit van deze voorwerpen die overal in het interieur stonden opgesteld, de muren bedekten en aan het plafond hingen (afb. 3). Liefkes had toen al bepaald dat Rijksmuseum Volkenkunde de erfgenaam zou worden van deze prachtige Indonesië-collectie. ${ }^{2}$

Frits Liefkes werd op 21 juli 1930 in Den Haag geboren en is daar op 20 maart 2010 overleden. Na een universitaire studie Kunstgeschiedenis was hij van 1965 tot 1987 conservator meubelen bij het Rijksmuseum in Amsterdam. Hij was vooral geïnteresseerd in Europese meubelen uit de $19^{\mathrm{e}}$ en $20^{\mathrm{e}}$ eeuw, en hij heeft voor dit museum een aantal zeer belangrijke aankopen gedaan. ${ }^{3}$ Frits Liefkes woonde zijn leven lang in Den Haag, voor een belangrijk deel samen met zijn partner, de antiquair Cor Weegenaar. Hun huis was een ware schatkamer, niet alleen van Indonesische kunst, maar ook van collecties tin, porselein, prenten en meubelen in verschillende stijlen.

Vlak voor zijn overlijden heb ik Frits Liefkes nog bezocht. Hij was erg verzwakt, maar gaandeweg het gesprek over de stukken die hem zo dierbaar waren leefde hij helemaal op. We spraken over zijn eerste Indonesische beeldje, een voorouderfiguur uit Nias, dat hij van zijn vader had gekregen voor zijn eindexamen. En over zijn grote verzameling textielen uit alle delen van de archipel. Hij liet een gouden kwispedoor uit Java zien, door zijn aankoop van de smeltoven gered. En hij wees op twee schitterend gedecoreerde stoelen uit Bali ( $\mathrm{afb} .4$ ), die nog waren gebruikt als zetel van de resident bij de verfilming van Louis Couperus' De Stille Kracht. Wat vooral naar voren kwam in het gesprek was de passie van Frits Liefkes voor schoonheid, en zijn respect voor het vakmanschap van Indonesische kunstenaars en ambachtslieden.

\section{Goud, meubelen en textiel}

De tentoonstelling geeft inzicht in de passie van een belangrijke verzamelaar en laat tegelijkertijd een aantal bijzondere topstukken uit de collectie zien. Liefkes verzamelde heel breed: de bijna duizend voorwerpen uit Indonesië zijn afkomstig uit alle delen van de archipel, van Aceh in het westen tot Papua in het oosten. Een heel klein aantal hiervan dateert uit de prehistorie 


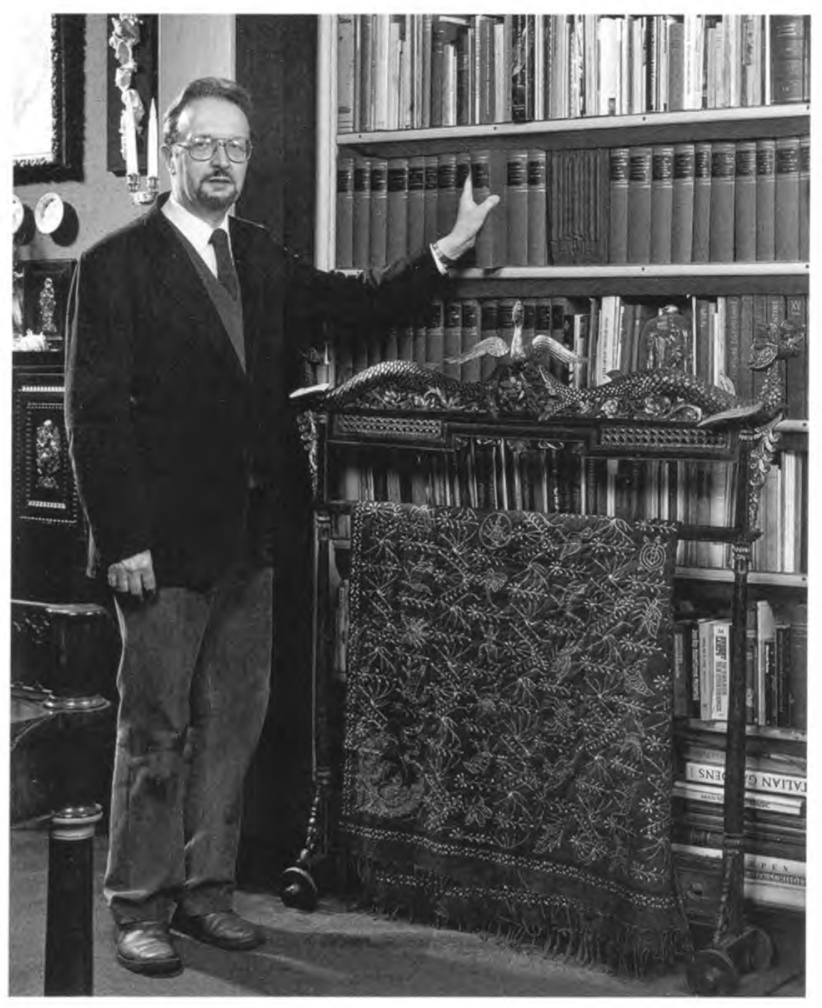

of de klassieke periode van de Indonesische kunstgeschiedenis, maar het merendeel is vermoedelijk gemaakt in de tweede helft van de $19^{e}$ of het begin van de $20^{\mathrm{e}}$ eeuw. Ook inhoudelijk is de verzameling heel gevarieerd, van batik tot wayang, van wapens tot schilden, van voorouderbeelden tot hofkunst, waarbij er vooral op het gebied van batik, meubelen en goud een aantal unieke stukken is te bewonderen.

Hoewel hij conservator van vooral Europese meubelen was geweest, was Liefkes ook zeker geïnteresseerd in Indonesisch meubilair. Behalve de al genoemde unieke stoelen uit Noord-Bali ${ }^{4}$ verzamelde hij een aantal bijzondere tafeltjes en een besnijdenisbankje uit Java, stukken die Rijksmuseum Volkenkunde nog niet bezat.

Frits Liefkes hield erg van textiel, en met meer dan 450 stuks vormt dit de grootste categorie binnen zijn verzameling. Vooral enkele van zijn batiks, waaronder een bijzondere batik uit Cirebon (afb. 5) die met bladgoud (prada) is belegd, behoren tot de topstukken in de tentoonstelling. ${ }^{5}$ Maar ook veel weefsels uit Sumatra, zoals schitterende goudbrokaat (songket) doeken uit Minangkabau en Palembang zijn van groot belang (afb. 6). ${ }^{6}$

Naarmate zijn collectie groeide, kreeg Frits Liefkes steeds meer oog voor de schoonheid van goud. Grote indruk op iedere bezoeker maakten twee vitrinekasten op de eerste verdieping van zijn huis, helemaal gevuld met blinkende gouden voorwerpen, ware juweeltjes van goudsmeedkunst (afb. 1). Tot nu toe bevatte de collectie etnografisch Indonesisch goud in Rijksmuseum Volkenkunde vooral sieraden en kostbare gebruiksvoorwerpen uit koninkrijken en sultanaten die waren verzameld in de koloniale periode. Daarentegen verzamelde Liefkes vooral de categorieën gouden objecten die pas vanaf de jaren '70 van de vorige eeuwn op de markt kwamen, zoals free access 


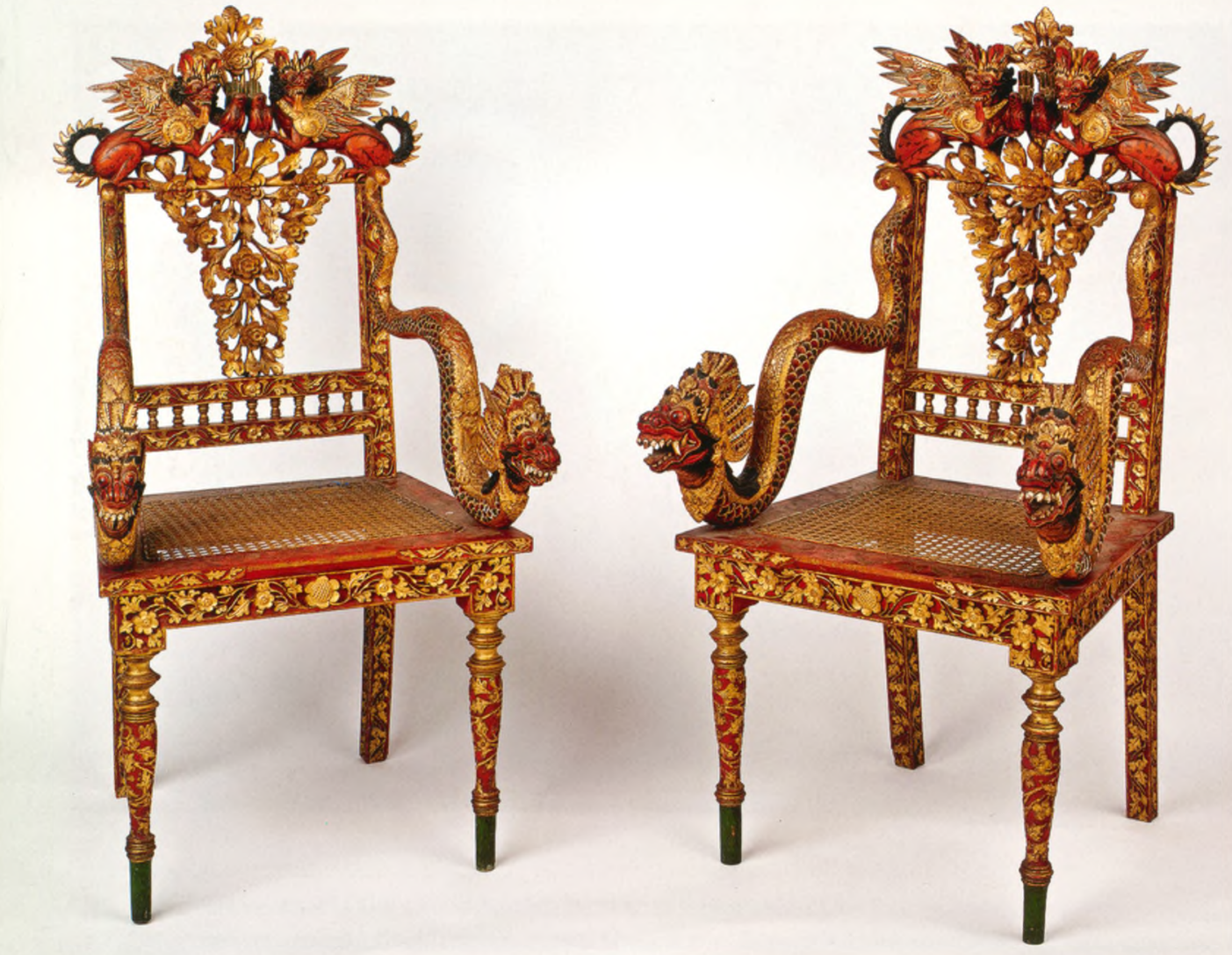

Afbeelding 4

Twee stoelen, hout, pigment, $111 \times 55 \times 55 \mathrm{~cm}$., $110 \times 52,5 \times 55 \mathrm{~cm}$., Buleleng (Noord-Bali), 1900-1940, Rijksmuseum Volkenkunde, Liefkes 206 a-b

\section{Versiering van mens en ruimte}

De voorkeur die Frits Liefkes aan de dag legde voor het verzamelen van fraaie textielen en juwelen had te maken met het feit dat voor hem een sieraad of een versierde doek niet zomaar een mooi voorwerp was, hij zag er ook de schoonheid in van de mannen en vrouwen die de sieraden gedragen hadden. Het thema van 'de versierde mens' sprak hem bijzonder aan. Niet voor niets was een van zijn lievelingsboeken Man as Art, over bijzondere vormen van lichaamsversiering in Oceanië. ${ }^{9}$ Liefkes verzamelde zelfs twee versierde schedels, van een Papua en een Dayak-man. In zijn collectie bevinden zich niet alleen doeken die als kleding voor mannen en vrouwen werden gebruikt, als heup-, schouder- of hoofddoek, maar ook genaaide kledingstukken, hoofddeksels, schoenen, sieraden en accessoires zoals gordels en gespen, haarpinnen en spelden.

Hierbij beperkte hij zich niet tot juwelen van goud of zilver, maar hij verzamelde ook sieraden gemaakt van ivoor, hout, snavel van de neushoornvogel, kralen, veren en schelpen. Ook de fraai gedecoreerde (sier)wapens, zoals Balinese krissen, Sumatraanse messen (badik), een Papua dolk (ase pasua) en een mes uit Kalimantan (mandau) zijn in zekere zin te beschouwen als behorend bij het thema 'de versierde mens'. Dit geldt bijvoorbeeld ook 


\section{Afbeelding 5}

Batik prada, heupdoek, machine geweven stof, natuurlijke verfstoffen, $107 \times 271 \mathrm{~cm}$., Cirebon (West-java), ca. 18601875, Rijksmuseum Volkenkunde, Liefkes 655

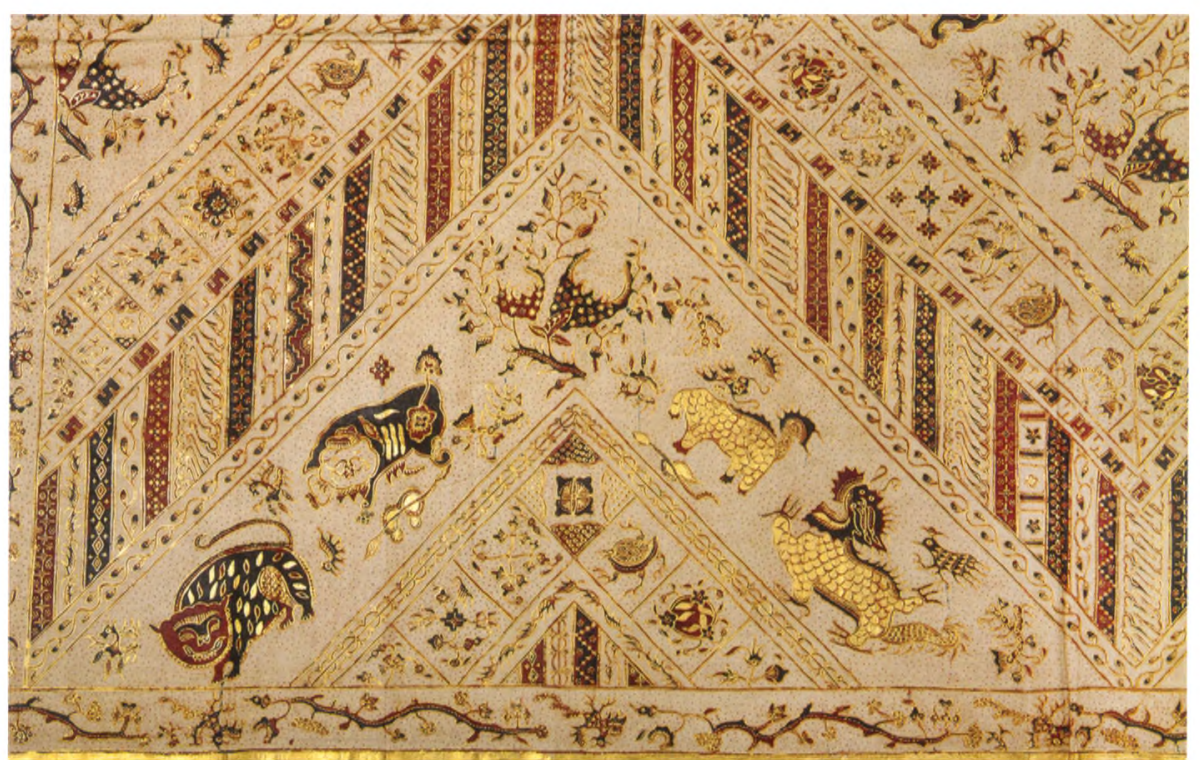

voor kunstig gevlochten en met kralen versierde sirih- en tabaksdoosjes en -tasjes van het eiland Timor.

Kleding, sieraden en accessoires maken mensen niet alleen mooier, maar verlenen hem of haar ook betekenis, door het benadrukken van identiteit, status en positie in de maatschappij.

Veel verschillende categorieën mensen zijn op deze manier vertegenwoordigd in de Liefkes-collectie: hij verzamelde bijvoorbeeld niet alleen een gouden hoofdtooi voor een Balinese danseres, maar ook één voor een adellijke vrouw uit Nias, niet alleen een zonnehoed versierd met kralen voor een Kenyah man, maar ook een hoofddeksel vervaardigd van fjn gevlochten palmblad, versierd met kleine edelsteentjes voor een Buginese man van hoge status. Vooral in de meer hiërarchisch geordende samenlevingen in Indonesië hebben de kostuums en juwelen die worden gedragen door een bruidspaar op hun trouwdag een "koninklijke" connotatie aangezien bruid en bruidegom worden beschouwd als koninklijk paar op deze speciale dag (raja sehari).

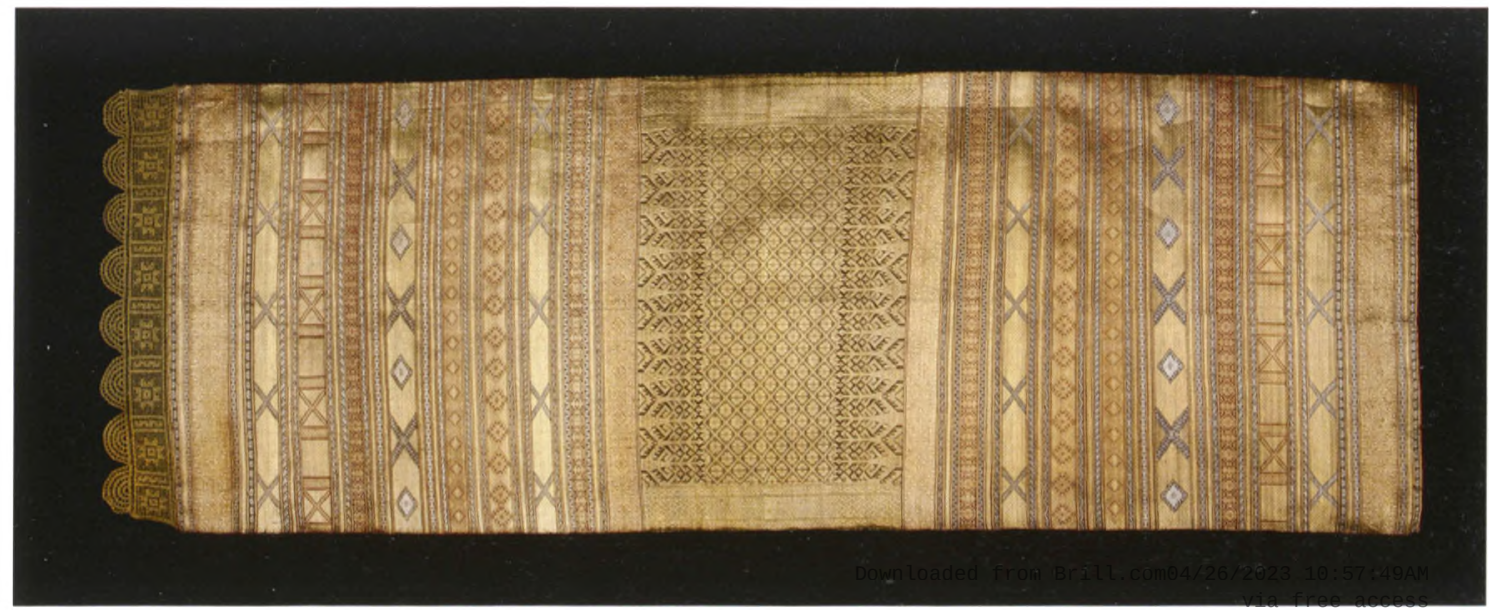



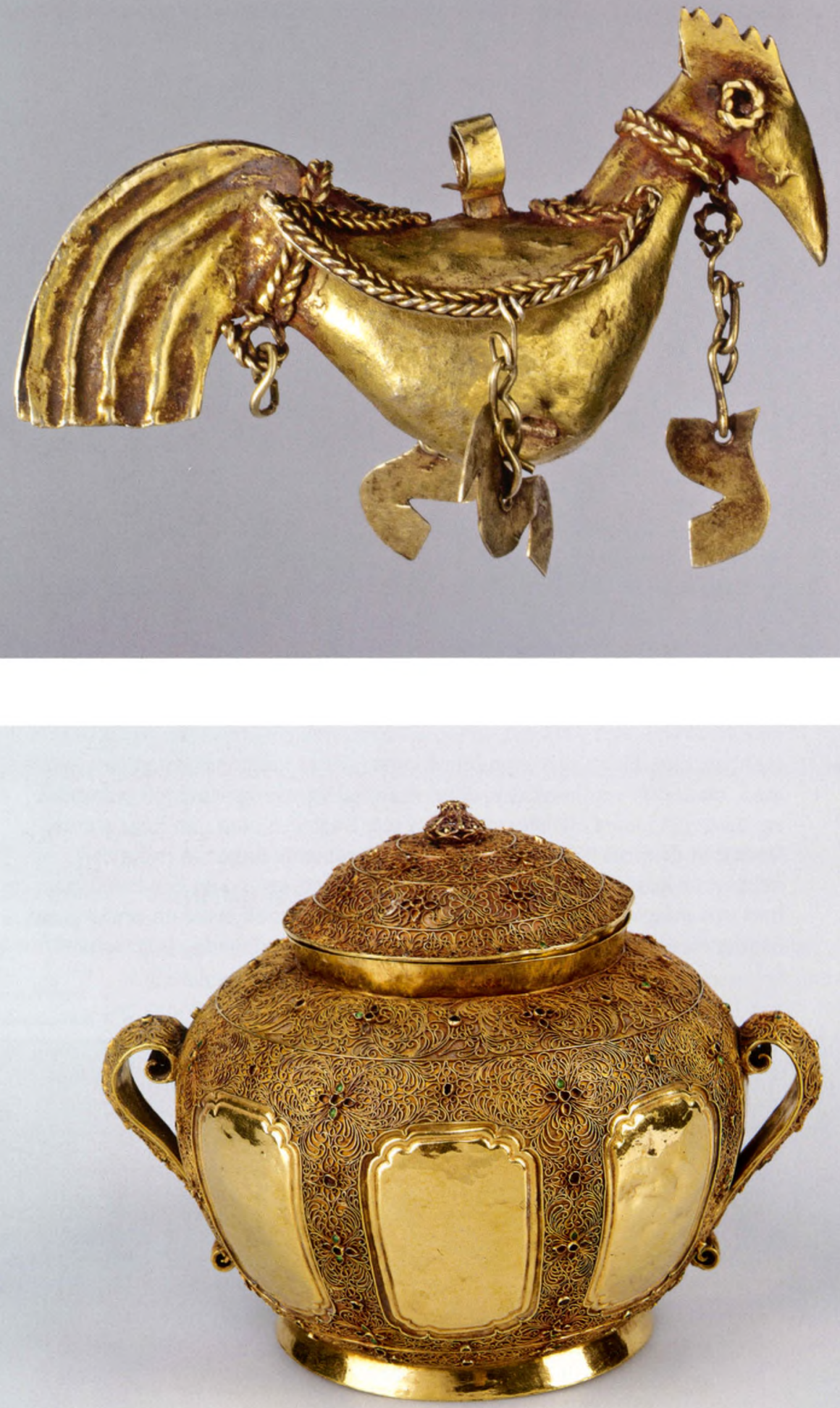


\section{Afbeelding 7 Hanger in de vorm van een haan, goud, 4,2 $\times$ 6,2 cm., Tanimbar (Molukken), $19^{e}$ eeuw, Rijksmuseum Volken- kunde, Liefkes 451}

Een ander aspect van het thema 'de versierde mens' is het feit dat in veel Indonesische samenlevingen textiel en sieraden van metaal worden uitgewisseld als geschenken bij bruiloften en worden geclassificeerd als respectievelijk vrouwelijke en mannelijke objecten. Voorbeelden in de collectie zijn de beroemde mamuli (oorsieraden) en weefsels uit Sumba in Oost-Indonesië, maar men vindt hetzelfde principe bijvoorbeeld ook bij de Minangkabau in West-Sumatra.

Enkele beelden die Frits Liefkes had verzameld, zoals voorouderbeeldjes uit Nias en beelden van een prinselijk paar uit Bali, tonen hun culturele identiteit door de kleding en sieraden die erop zijn geschilderd of in het hout zijn uitgesneden. Maar Liefkes hield er ook van om de wat grotere beelden in zijn collectie zelf te voorzien van doeken, kettingen of armbanden. De hoofdtooi van een heel bijzonder ivoren voorouderbeeldje uit Tanimbar had hij bijvoorbeeld versierd met kleine gekleurde veertjes van zijn kanarie. Als conservator meubelen en als verzamelaar wonende met en tussen zijn objecten, die deel uitmaakten van zijn interieur, verzamelde Liefkes niet alleen stukken die te maken hebben met 'de versierde mens', maar ook met de decoratie van de leefomgeving van de Indonesische mensen die deze objecten maakten en gebruikten. Kisten en kasten uit Palembang (Sumatra) en Java, met houtsnijwerk versierde deuren uit Kalimantan en Bali, een wanddecoratie van kralenwerk uit Lampung, kris- en lanshouders uit Java en Bali, een gedecoreerd batik rek uit Java en nog veel meer van dergelijke stukken hadden nu een prominente plaats in het interieur van de verzamelaar gekregen. Zij fungeerden hier deels om bijvoorbeeld doosjes van lakwerk en schenkkannen (kendi) en sirih-stellen van zilver in en op uit te stallen. In hun oorspronkelijke culturele context hadden deze voorwerpen, naast het zuiver functionele aspect, vaak ook een rol gespeeld als siervoorwerp waarvan de eigenaar kon genieten en waarmee hij kon pronken.

Net als in Indonesië, waar objecten ook van eigenaar veranderen door (ruil)handel en geschenkenuitwisseling, was Frits Liefkes steeds actief bezig met zijn collectie. Hij kocht op veilingen en van kunsthandelaars, ruilde met vrienden, verkocht stukken om betere aankopen te kunnen doen, en liet nieuwe aanwinsten vol trots zien aan vrienden en collega's.

\section{Voortbestaan}

Hoewel op het eerste gezicht de Liefkes-collectie weinig voorwerpen bevat die te maken hebben met religie en ritueel, hebben de thema's van versiering van mens en omgeving toch ook vaak een religieuze betekenis. Liefkes verzamelde niet alleen mooie voorouderbeelden (zoals een fraaie korwar) en priesterattributen, bijvoorbeeld een medicijnhoorn (naga morsarang) van een Batak priester (afb. 9), maar veel van zijn weefsels, sieraden of meubels hadden ook een rituele functie.

Speciale kleding en juwelen kunnen bijvoorbeeld alleen bij bepaalde rituele gelegenheden worden gedragen, zoals huwelijken; sommige doeken worden gebruikt bij dodenrituelen als ceremoniële bedekking van de lijkkist, terwijl veel andere textielen en objecten worden gebruikt om rituele ruimtes mee 'aan te kleden'. Op de tentoonstelling wordt een vlag (umbul-umbul) voor ritueel gebruik uit Bali getoond, naast een prachtige, meer dan vijf meter lange sarita doek en versieringen van kralen (kandaure) uit Tana Toraja (Sulawesi) en ook de beroemde tampan en palepai weefsels uit Lampung zullen niet ontbreken, om maar een paarvoorbeelden te noemen 0 . 


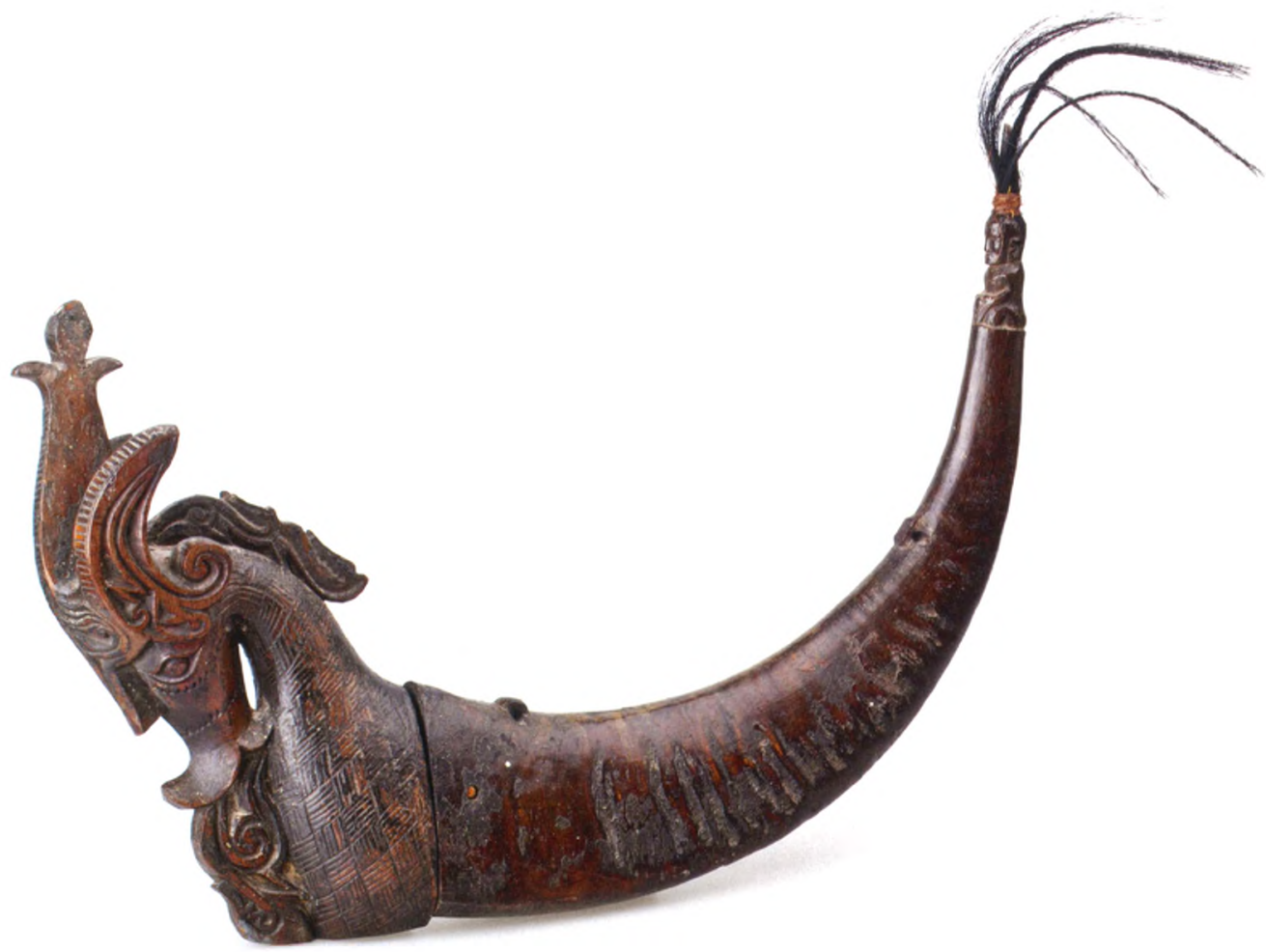

Afbeelding 9 Medicijnhoorn van een priester (naga morsarang), hout, buffelhoorn, paardenhaar, $44 \times 79 \times 11 \mathrm{~cm}$., Toba Batak (Sumatra), $19^{e}$ eeuw, Rijksmuseum Volkenkunde, Liefkes 44
De verschillende sirih-stellen zijn niet alleen belangrijk in het sociale leven, omdat het aanbieden van sirih een teken is van gastvrijheid, vriendschap en respect, maar zij hebben ook een rituele functie, want de sirihpruim (een genotmiddel bestaand uit een combinatie van sirihblad, pinangnoot en kalk, waarop gekauwd wordt) is in heel Indonesië gerelateerd aan de voorouders en wordt gebruikt in offers en rituele maaltijden.

In Indonesië zijn individuen nauw verbonden met hun familie en sociale gemeenschap, en hoewel de meeste mensen behoren tot een van de grote godsdiensten, is de nagedachtenis aan de voorouders voor velen van hen ook heel belangrijk. Voorouderbeeldjes uit Nias en Tanimbar zijn een uiting van het idee dat de levenden worden beschermd door de voorouders waarvan de geest voortleeft na de dood en die als bemiddelaars fungeren tussen hemel en aarde. Net zoals het geval is met de verzamelingen uit Indonesië in Rijksmuseum Volkenkunde, is de levenscyclus van individu en maatschappij ook een van de thema's in de Liefkes-collectie. Het voortbestaan of de continuiteit van het leven is te zien in een grote verscheidenheid aan voorwerpen, waarvan motieven en kleuren een betekenis hebben die te maken heeft met vruchtbaarheid en bescherming from Brill.come4/26/2023 10:57:49AM 
Zo wordt in Kalimantan het leven van een klein kindje dat wordt gedragen in een babydraagmand, beschermd door demonische gezichten die op de achterkant hiervan zijn uitgesneden. Op Bali beschermt de kop van een krachtige, mythische vogel die naar achteren kijkt, garuda mungkur, de drager van de hoofdtooi waarop deze decoratie is aangebracht. Veel soorten sieraden, zoals armbanden, ringen en kettingen bevatten niet alleen boodschappen over status en identiteit van de drager, maar hebben tegelijkertijd ook een beschermende functie.

De decoratieve motieven op veel objecten in de Liefkes-collectie staan in relatie tot het voortbestaan van het leven van mensen, dieren en planten, onder de kosmische invloed van zon en maan. Goede voorbeelden hiervan zijn de vele verschillende motieven op batik doeken uit Java en weefsels uit Sumatra en Sumba, de symbolen op de sarita doeken uit Sulawesi, en de voorouderfiguren op de kralen kleding uit Kalimantan. Levensbomen, een soort kosmos in miniatuur, zijn te zien op de Javaanse wayang lamp en het besnijdenisbankje, maar ook op de tampan weefsels uit Lampung. Vruchtbaarheid en bescherming in de gedaante van belangrijke vogels, slangen en andere dieren, worden op Java en Bali uitgedrukt door de vogel Garuda en gekroonde slangen (naga), in Kalimantan door de neushoornvogel en de waterslang (in het zogenoemde aso-motief), bij de Batak door de singa figuur (afb. 9) en in Oost-Indonesië door de haan (afb. 7).

Omdat ze steeds op volgende generaties werden overgedragen door de voorouders, beschermen sommige objecten als kostbare erfstukken (pusaka) de nakomelingen, en zorgen zij voor het voortbestaan van het leven van de afstammingsgroep. $\mathrm{Zij}$ liggen veilig opgeborgen hoog in de nok van de familiehuizen, en hun verhalen maken deel uit van hun beschermende kracht. Eén zo'n bijzonder erfstuk, een ivoren beeldje van de belangrijke voorouder teran So Cornelis uit Tanimbar, ${ }^{10}$ maakt nu deel uit van de Liefkescollectie.

Drie jaar geleden, in maart 2010, bij het overlijden van Frits Liefkes, ontving Rijksmuseum Volkenkunde al zijn schatten uit Indonesië, die zozeer deel hadden uitgemaakt van zijn leven en van zijn huis.

De naam van Frits Liefkes zelf zal ook voortleven dankzij zijn bijzondere collectie en het boek Living with Indonesian art: the Frits Liefkes collection dat hierover zal verschijnen. Bovendien heeft hij een fonds nagelaten aan ons museum, het Weegenaar-Liefkes fonds, waaruit nieuwe aanwinsten op het gebied van Indonesische kunst en materiële cultuur kunnen worden gefinancierd. Een aantal van deze nieuwe aanwinsten zal ook op de expositie te zien zijn.

Door zijn privé-verzameling nu deel te laten uitmaken van een openbare collectie, heeft Frits Liefkes niet alleen bijgedragen aan het behoud van belangrijk cultureel erfgoed uit Indonesië, maar bovendien ook aan het toegankelijk maken van de prachtige voorwerpen voor iedereen die hiervan wil genieten.

\section{Te zien}

- Tentoonstelling van stukken uit de collectie van Frits Liefkes. Rijksmuseum Volkenkunde, Leiden - 9 mei tot 21 juli 2013. 
gewerkt bij de Rijks Universiteit Leiden, het KITLV en de Stichting Pelita. Zij heeft een aantal tentoonstellingen georganiseerd in samenwerking met het Nationaal Museum van Indonesië in Jakarta. Haar specialisatie is de rituele kunst van Bali en de geschiedenis van hofkunstcollecties in de musea in Leiden en Jakarta.

\section{Literatuur}

Francine Brinkgreve and David J. Stuart-Fox (eds.), Living with Indonesian Art: The Frits Liefkes collection, Rijksmuseum Volkenkunde/ KIT Publishers,

Leiden/Amsterdam, te verschijnen 2013.

Jerome Feldman (et al.), Nias tribal treasures: Cosmic reflections in stone, wood and gold, Volkenkundig Museum Nusantara, Delft, 1990.

Malcolm Kirk (photographs) and Andrew Strathern (introduction), Man as Art: New Guinea body decoration, Thames and Hudson, London, 1981.

Rita Wassing-Visser, Sieraden en lichaamsversiering uit Indonesië, Volkenkundig Museum Nusantara, Delft, 1984 [tentoonstellingscatalogus].

\section{Noten}

1. Dit artikel is gebaseerd op mijn artikel "A collector's Indonesia; the Frits Liefkes collection in Rijksmuseum Volkenkunde" in Brinkgreve and Stuart-Fox (eds.) 2013. Dit boek bevat artikelen van meer dan 20 auteurs over 175 topstukken uit de collectie van Frits Liefkes, en zal verschijnen bij de opening van de tentoonstelling. De foto's bij dit artikel zijn gemaakt door Ben Grishaaver en Ingrid Gerritsen.

2. Ik wil ook hier graag Jan Veenendaal hartelijk bedanken voor alles wat hij in dit verband voor Rijksmuseum Volkenkunde heeft gedaan.

3. Zie de biografie van Frits Liefkes, geschreven door Wouter Kloek en Jan Veenendaal, in Brinkgreve and Stuart-Fox (eds.) 2013.

4. Zie het artikel over deze stoeltjes door Hedi Hinzler, in Brinkgreve and Stuart-Fox (eds.) 2013

5. Zie het artikel over batik door Rens Heringa, in Brinkgreve and Stuart-Fox (eds.) 2013.

6. Zie de artikelen over weefsels uit Sumatra door Linda Hanssen, in Brinkgreve and Stuart-Fox (eds.) 2013.

7. Zie de artikelen van Maggie de Moor en Nico de Jonge in Brinkgreve and Stuart-Fox (eds.) 2013.

Een aantal van deze gouden juwelen, met name die uit Nias en Sumba, heeft Liefkes uitgeleend voor twee tentoonstellingen in Museum Nusantara in Delft. Zij zijn gepubliceerd in Wassing-Visser 1984: voorplaat, pl. 95 (cat. no. 462); en in Feldman (et al.) 1990: pl. 145, 155, 167.

8. Zie de artikelen van respectievelijk Jan Veenendaal, Rita Wassing en Sirtjo Koolhof over deze voorwerpen in Brinkgreve and Stuart-Fox (eds.) 2013.

9. Kirk 1981.

10. Zie het artikel van Nico de Jonge in Brinkgreve and Stuart-Fox (eds.) 2013. 